\title{
Developing Assessment Model of a Tennis Forehand Stroke as Biomechanics Movement Perspective
}

\author{
Ricko Irawan $^{1}$, Agus Raharjo ${ }^{2}$, Lulu April Farida ${ }^{3}$ \\ \{rickoirawan33@gmail.com ${ }^{1}$, agusraharjo@mail.unnes.ac.id ${ }^{2}$, lulu.farida@mail.unnes.ac.id ${ }^{3}$ \} \\ Universitas Negeri Semarang, Semarang, Indonesia ${ }^{123}$
}

\begin{abstract}
The wrong biomechanic motion was allegedly made the results of the blow not optimal to the tennis player. The problem of this research is the absence of test instruments and biomechanical motion measurement forehand stroke techniques. The purpose of this research is to make an assessment instrument refers to the movement of biomechanics forehand stroke techniques. The method used in this study is Research and Development. The data used qualitative and quantitative data. The research instrument developed was the FED-0.5 assessment instrument. The results of the study regarding the suitability of the product of the 5 developed test items, namely: 1 ) foundation $=83.3 \%$ very high, 2 ) rotation $=83.3 \%$ very high, 3 ) position of strength $=75 \%$ good, 4 ) impact $=91.7 \%$ very high, and 5 ) followthrought $=75 \%$ good. Conclusion that the 5 instrument products can be used in the development of biomechanical motion assessment forehand stroke techniques.
\end{abstract}

Keywords: biomechanics of motion, instruments, achievements

\section{Introduction}

Perfection in playing tennis becomes the main goal in obtaining desired achievements. like a building, the blow technique is the main foundation in the development of other aspects such as physical, tactic and mental. when the player's technique is correct, it will affect the sustainability of the player's achievements, because seen from the biomechanics of the motion, the player who has the correct technique will make the movement more effective and efficient. effective movement will produce explosive power but the energy expended is relatively smaller.

The achievement of tennis players who are "stuck" frustrates many players. This was identified because the mastery of the tennis player technique was not optimal. Improper mastery of techniques causes injury to the player. So that it will inhibit the talent and potential of athletes in developing their achievements. Injuries in tennis are various types such as shoulder injuries, back injuries, elbows, knee injuries, ankle injuries and so forth. According to RSON during 2015 in Indonesia the average incidence of injuries in tennis was $6.3 \%$ [1].

One of the basic techniques of tennis blows is the forehand, the forehand is one of the earliest hits controlled by the majority of players than the other techniques. 
Forehand is the main basis for playing tennis [2]. The key to a perfect forehand is to develop an aggressive initial approach [3]. A large punch speed will produce a hard punch or a large force [4].

The perfection of the forehand technique is important so that the player can perform as much as possible and of course prevent the body from injury. Results of field observations and interviews with Central Java PON trainers. Enrico Satria said "many players are hampered by their achievements due to injuries, injuries caused by excessive stress and trauma during matches such as the result of knees that often make rounds on forehand blows". [5] concluded that tennis players experience psychological distress and stress directly related to wrist injuries, and sprains.

Seeing the facts above, the researcher concludes that in making forehand movements, it must be done with perfect biomechanical movements, but there are no instruments and parameters for the assessment of biomechanical movements of forehand techniques for advanced athletes / specific achievements so as to cause athlete punches to be ineffective and not optimal. This is a problem for the majority of trainers to develop an instrument of motion assessment for biomand forehand, it is important to make an assessment instrument to create high-tech athletes and athletes who are not susceptible to injury.

\subsection{The Novelty of Researches Result}

This study was designed on the basis of previous researches, the following were previous researches became a benchmark in designing this study:

1. Kamal Firdaus Research in the Journal of Indonesian Sports Science Media in 2011 with the title Evaluation of the Field Tennis Sports Development Program in the city of Padang. This study aims to evaluate the selection of athlete acceptance selection [6].

2. Beni Agus Prasetiono (2018) The results of this study produce a test of the skills of a tennis tennis player [7].

3. Panchal (2019) produced an evaluation instrument for biomectical disectomy and cervical anterior (ACDF) in treating symptomatic disc degeneration, segmental instability and trauma to the cervical spine [8].

4. Liu (2019) produced a multilevel ACCF performance improvement assessment instrument [9].

5. El Daou (2018) produced a new robot plafrom development product for testing the hip aspect of biomechanical motion [10].

6. Wang (2018) produced a portable exoskeleton development product for hand rehabilitation for motor repair of all upper limbs and motor recovery in the tag and finger function [11].

From some of the literature studies above then summarized through FGD activities conducted by a research team and 2 field tennis experts and 1 national level tennis coach, then the results of the discussion are packaged into a product of test instruments and biomechanical motion measurement forehand technique. 


\section{$2 \quad$ Materials And Methods}

The design of this study uses Research and development. The data used in this study are qualitative and quantitative data. The sampling technique uses purposive sampling. The product developed in this research is in the form of developing an assessment instrument with data collection techniques using interviews, observations, questionnaires, tests \& measurements and documentation. This research is used in tennis sports that are adjusted to actual technical conditions such as the evaluation of athlete's biomechanics. This study aims to produce a product in the form of an FED0.5 assessment instrument that is suitable for the level of tennis athlete's needs. Development procedures in this study are: 1). Conduct product analysis, 2) Develop initial product assessment instruments FED-0.5, 3) Expert validation, 4) Product trials and 5) Product revisions.

Trial The FED-0.5 assessment instrument product uses the Sukun Tenis Club athlete, previously a small scale trial was validated by experts in accordance with this field of research. To validate the product to be produced, researchers involved 2 (two) field tennis experts from lecturers and 1 (one) PON tennis court trainer. Variables evaluated by experts include foundation, unit turn, power position, racket lag and followthrough.

Collecting data from experts is done by providing an initial model draft accompanied by an evaluation sheet to the expert. Draff evaluation results from experts in the form of assessments and suggestions for instruments that have been made, are used as a basic reference for the development of the assessment instrument forehand technique.

Trials are conducted to obtain responses and product revisions, so that the final product will be produced in the form of an FED 0.5 assessment instrument that suits the needs of athletes at the level of achievement. This study uses an experimental design as a trial design. The trials are conducted in small group trials and and large group trials or field trials. Small-scale trials involving athletes of UKM FIK Unnes, amounting to 10 people, 2-3 meetings and large-scale trials involving Sukun Tenis Club athletes, amounting to 18 people 1 meeting. Researchers after receiving input from experts then carry out product revisions. Revisions were made to improve the product before the final product was used.

The data analysis technique used is the percentage for analyzing and evaluating the developer's subject in assessing the level of eligibility, quality, and product acceptance in the form of data from the foundation, rotation, position, strength, impack and followtrought assessment. Respondents are categorized into three categories, namely: good (Mean Score + 1 sd up), Medium (Mean -1 up to Mean Score + 1), Less (Mean -1 up and down).

\section{$3 \quad$ Result and Discussion}

Small-scale product trials are intended to test the feasibility of using the product and get input or suggestions. Targets of small-scale product trials are 2 field tennis lecturers and 1 National level tennis coach. The results of small-scale product trials can be seen in the following table: 
Table 1. Expert Evaluation Result

\begin{tabular}{|c|c|c|c|c|c|c|c|}
\hline \multirow{2}{*}{ No. } & \multirow{2}{*}{ Aspects } & \multirow{2}{*}{ Testing parameters } & \multicolumn{4}{|c|}{ Scales } & \multirow{2}{*}{$\begin{array}{l}\text { Total } \\
\text { respondens }\end{array}$} \\
\hline & & & 1 & 2 & 3 & 4 & \\
\hline 1. & & Foundation & & & 1 & 2 & 3 \\
\hline 2. & Biomechanics & Unit turn & & & 2 & 1 & 3 \\
\hline 3. & Movement of & Power position & & & 3 & & 3 \\
\hline 4. & Tennis Fore- & Racket lag & & & 1 & 2 & 3 \\
\hline 5. & hand Stroke & Followthrough & & 1 & 1 & 1 & 3 \\
\hline \multicolumn{2}{|c|}{ Total } & & & 1 & 8 & 6 & \\
\hline \multicolumn{2}{|c|}{ Percentage } & & & $6,67 \%$ & $53,33 \%$ & $40 \%$ & \\
\hline
\end{tabular}

Table 2. Expert Evaluation Percentage

\begin{tabular}{|c|c|c|c|c|c|}
\hline No. & Subject & $\begin{array}{l}\text { Quality } \\
\text { answers }\end{array}$ & Conclusion & Classification & Recommendation \\
\hline 1. & Foundation & 83,3 & valid & very high & use \\
\hline 2. & Unit turn & 83,3 & valid & very high & use \\
\hline 3. & $\begin{array}{l}\text { Power posi- } \\
\text { tion }\end{array}$ & 75,0 & valid & high & use \\
\hline 4. & Racket lag & 91,7 & valid & very high & use \\
\hline 5. & Followthrough & 75,0 & valid & high & use \\
\hline
\end{tabular}

The data analysis table in the appendix of the results of filling in the expert's assessment of the suitability of the product with physical test parameters, can be concluded as follows:

Aspect of product compatibility with the aspect of foundation assessment obtained a percentage of $83.3 \%$. Based on predetermined criteria, the aspect of product conformity with aspects of the foundation assessment in the movement of forehand biomechanics has met the very high criteria so that this product can be used.

Aspects of product compatibility with the round assessment aspects obtained a percentage of $83.3 \%$. Based on predetermined criteria, the aspect of product conformity with the aspect of unit turn assessment in the forehand motion biomechanics meets the criteria very well so that this product can be used.

Aspects of product compatibility with aspects of the assessment of the power position in the movement of forehand biomechanics obtained a percentage of $75 \%$. Based on predetermined criteria, the aspect of product conformity with aspects of the assessment of strength positions has met the criteria well so that this product can be used.

Aspects of product compatibility with the racket lag assessment aspect obtained a percentage of $91.7 \%$. Based on predetermined criteria, the aspect of product suitability with aspects of impact assessment in the movement of forehand biomechanics has met the criteria very well so that this product can be used.

The product conformity aspect with the followthrought assessment aspect obtained a percentage of $75 \%$. Based on the established criteria, the aspect of product conformity with the followthrought aspect in the movement of forehand biomechanics has met the criteria well so that this product can be used. 
Based on the results of small-scale trials that have been validated by experts, it will be discussed further about the correlation of instrument products with related theories.

The foundation in motion biomechanics before doing forehand techniques, one of which is the truth in doing good and right grip techniques. The most correct grip in the forehand technique is the estern grip. The right athlete using the grip will help make effective and dynamic movements. In research (Roy T.P, Kiyatno, Siswandari, 2017) concluded that grip has a contribution in the biomotor ability of the forehand technique [12].

The unit turn has a great influence on the biomechanical motion of the forhand stroke technique. The body rotation that is elastic and fast will automatically be able to gather energy to be expended. When a player is going to make optimal lap movements, of course, it is necessary to suggest that the agility is moving and the mindset is fast. (Ismalasari, 2010) suggests that speed of thinking and agility in moving are required to perform the forehand technique [13].

The power position in a forehand is very important, because the position of strength will later differentiate between the athlete's punch from one another. Maximum strength must be done properly and correctly. Starting from the shoulder position, chin position, hands that do not hit and the position of the body and elbows must perform its function correctly and in a regular series of movements. (La Sawali, 2018) to get the maximum forehand results must be done with a regular series of motion [14].

When a racket hits the ball or is often called an impact ball, the impact must be done at perfect momentum. The better the momentum, the better ball will be produced. The speed, direction and consistency of a good ball depends on the impact made by an athlete. The correct impact is the eyes focus on the ball, the racquet face is slightly horizontal and body weight is channeled forward through the bent left knee (if the player is right-handed) and the ball's shooting distance is not too far from the body. (Palmizal, 2011) when the ball is not too tight and not too far away so the hands are straight. This will affect the balance and control of the ball [15].

\section{Conclusion}

In the validation trials that have been done by 3 field tennis experts, that product suitability for the test instrument and biomechanical motion measurement forehand techniques can be accepted which include: foundation, turn unit, power position, racket lag and followthourgh.

\section{Acknowledgements}

We would like to thank Faculty of Sports Science, Universitas Negeri Semarang, Indonesia for the funding. 


\section{References}

[1] Supartono B. Karakteristik Cedera Pada Kompetisi Olahraga Cabor Tenis, Sepeda Gunung, Sepakbola, Taekwondo Dan Karate.

[2] Akhiruyanto A. Model Pendekatan Mini Tenis Dalam Pembelajaran Pukulan Forehand Drive Untuk Perkuliahan Tenis Lapangan. J. Penelitian Pend. 2010;27(1).

[3] Douglas CP, Dorland CC, inventors; Hewlett Packard Development Co LP, assignee. Method and apparatus for monitoring a network. United States patent US 7,975,043. 2011 Jul 5.

[4] Gunawan A, Sahadevan S, Neuhoff C, Große-Brinkhaus C, Gad A, Frieden L, Tesfaye D, Tholen E, Looft C, Uddin MJ, Schellander K. RNA deep sequencing reveals novel candidate genes and polymorphisms in boar testis and liver tissues with divergent androstenone levels. PloS one. 2013;8(5).

[5] Olmedilla A, Ortega E, Almeida P, Lameiras J, Villalonga T, Sousa C, Torregrosa M, Cruz J, Mas AG. Cohesión y cooperación en equipos deportivos. Anales de Psicología/Annals of Psychology. 2011;27(1):232-8.

[6] Firdaus K. Evaluasi Program Pembinaan Olahraga Tenis Lapangan di Kota Padang. Media Ilmu Keolahragaan Indonesia. 2011;1(2).

[7] Prasetiono BA, Gandasari MF. Model Rangkaian Tes Keterampilan Tenis Lapangan pada Pemain Putra Kelompok Usia 12-14 Tahun. J. SPORTIF: Jurnal Penelitian Pembelajaran. 2018 Nov 14;4(2):220-34

[8] Panchal R, Gandhi A, Ferry C, Farmer S, Hansmann J, Wanebo J. A Biomechanical Evaluation of a Next-Generation Integrated and Modular ACDF Device Possessing FullPlate, Half-Plate, and No-Profile Fixation Iterations. Global Spine Journal. 2019 Dec;9(8):826-33.

[9] Liu N, Lu T, Wang Y, Sun Z, Li J, He X. Effects of new cage profiles on the improvement in biomechanical performance of multilevel anterior cervical Corpectomy and fusion: a finite element analysis. World neurosurgery. 2019 Sep 1;129:e87-96.

[10] Daou HE, Ng KG, Van Arkel R, Jeffers JR, y Baena FR. Robotic hip joint testing: Development and experimental protocols. Medical engineering \& physics. 2019 Jan 1;63:57-62.

[11] Wang D, Meng Q, Meng Q, Li X, Yu H. Design and development of a portable exoskeleton for hand rehabilitation. IEEE Transactions on Neural Systems and Rehabilitation Engineering. 2018 Oct 30;26(12):2376-86.

[12] Putra RT, Kiyatno K, Siswandari S. Biomotor and Psychomotor Dominant Factors Analysis Determinants of Tennis Groundstroke Forehand Ability on Tennis Achievement Coaching of Students of Fkip Universitas Sebelas Maret, Indonesia. European Journal of Physical Education and Sport Science. 2017 Mar 17.

[13] Ismalasari R, Wibowo S. Pembinaan Olahraga Tenis Lapangan Ditinjau dari Aspek Biomekanik dan Kinesiologi.

[14] Sawali L. Drills forehand training strategy on the stroke of forehand drive ability in tennis. International journal of physical sciences and engineering. 2018 Jun 19;2(2):11-20.

[15] Palmizal A. Pengaruh metode latihan global terhadap akurasi ground stroke forehand dalam permainan tenis. Media Ilmu Keolahragaan Indonesia. 2011;1(2). 